\title{
Efficacy of Fungicides for Control of Entomosporium Leaf and Berry Spot of Saskatoon
}

\author{
Ralph M. Lange, Plant Pathologist, Alberta Research Council, Vegreville, AB Canada T9C 1T4; Piara S. Bains, \\ Research Scientist, Crop Diversification Centre-North, Alberta Agriculture, Food and Rural Development, \\ Edmonton, AB Canada T5B 4K3; and Ronald J. Howard, Leader, New Crop Development Unit, Crop Diversifi- \\ cation Centre-South, Alberta Agriculture, Food and Rural Development, Brooks, AB Canada T1R 1E6
}

\begin{abstract}
Lange, R. M., Bains, P. S., and Howard, R. J. 1998. Efficacy of fungicides for control of Entomosporium leaf and berry spot of saskatoon. Plant Dis. 82:1137-1141.

Studies were conducted to identify non-phytotoxic fungicides that would effectively control Entomosporium leaf and berry spot of saskatoon. Of 13 fungicides tested, benomyl, imazalil, myclobutanil, propiconazole, and thiophanate-methyl completely restricted in vitro radial growth of a monoconidial Entomosporium mespili isolate. Chlorothalonil, imazalil, propiconazole, and thiophanate-methyl completely inhibited conidiospore germination in vitro at $1 \mathrm{ppm}$ a.i., the lowest concentration tested. In 1995, chlorothalonil and propiconazole provided the best control of Entomosporium leaf and berry spot at three orchard test sites in Alberta, Canada, while benomyl was also effective at two of these sites. Multiple applications of chlorothalonil $\left(970 \mathrm{~g} \mathrm{ha}^{-1}\right)$ and propiconazole $\left(125 \mathrm{~g} \mathrm{ha}^{-1}\right)$ effectively reduced disease severity at two of three test sites in 1996.
\end{abstract}

Additional keywords: Amelanchier alnifolia, Fabraea maculata, serviceberry

Saskatoon (Amelanchier alnifolia Nutt.) is an important commercial fruit crop in the provinces of Alberta, Saskatchewan, and Manitoba, Canada. The area currently devoted to the crop in western Canada is 900 to 1,200 ha, with half of this area producing fruit. Fruit yields range from 4,000 to $7,000 \mathrm{~kg} \mathrm{ha}^{-1}$; producers currently earn $\mathrm{C} \$ 3.30$ to $\mathrm{C} \$ 6.60$ per $\mathrm{kg}$. Saskatoons are handpicked and sold via the "U-Pick" marketing system, for which an aesthetically pleasing product is an important requirement. Alternatively, the fruit is mechanically harvested for processing into pie fillings, jams, jellies, and syrups. Commercial food processors, who are the major purchasers of mechanically harvested saskatoons, also require an assured supply of high quality fruit. Entomosporium leaf and berry spot (ELBS), caused by Entomosporium mespili (DC.) Sacc., is a serious threat to commercial operations meeting

Corresponding author: P. S. Bains

E-mail: bains@agric.gov.ab.ca

This work was supported by the Alberta Agricultural Research Institute, the Canadian AgriFood Development Initiative and Farm Support and Adjustment Measures programs of Agriculture and Agri-Food Canada, the Fruit Grower's Society of Alberta, the Saskatchewan Agriculture Development Fund, and The Berry Basket (Clairmont, AB).

Accepted for publication 30 June 1998.

Publication no. D-1998-0731-03R

(C) 1998 The American Phytopathological Society demand in either of the markets described above because it causes spotting, cracking, and deformation of saskatoon fruit.

ELBS was of minor importance until 1990, when it caused havoc in the central and north-central areas of Alberta, resulting in large economic losses to growers $(6,16)$. By 1994 , the prevalence of this disease in northern and central areas of the province had increased to the extent that most of the fruit crop that year was destroyed (13). The majority of saskatoon orchards lost 80 to $90 \%$ of the crop, and cumulative financial losses were estimated at $\mathrm{C} \$ 1,000,000$. Consequently, the saskatoon industry began searching for means to effectively control the disease.

Unfortunately, very little information was available regarding control of ELBS. Until 1994, when triforine was registered for use on saskatoon, no registered fungicides were available for control of the disease. It was observed in 1994, however, that triforine did not effectively control ELBS in Alberta. Therefore, the major objective of this project was to identify non-phytotoxic fungicides that would effectively control this disease on saskatoon. This was accomplished by in vitro screening of candidate fungicides against $E$. mespili, and by evaluating fungicide efficacy in orchard trials.

\section{MATERIALS AND METHODS}

In vitro screening of fungicides against $\boldsymbol{E}$. mespili. Anilazine (Dyrene $50 \%$ WP), benomyl (Benlate $50 \mathrm{WP}$ ), chlorothalonil (Bravo 500), imazalil
(Fungaflor 75\% SP), iprodione (Rovral 50\% WP), mancozeb (Dithane 75\% DG), metalaxyl (Ridomil 24\% EC), myclobutanil (Nova $40 \mathrm{~W}$ ), propiconazole (Tilt 250 EC), tebuconazole (Folicur $45.6 \%$ DF), thiophanate-methyl (Easout $70 \mathrm{WP}$ ), triadimefon (Bayleton 50\% WP), and triforine (Funginex 190 EC) were evaluated for their effect on radial growth and conidiospore germination of E. mespili. $E$. mespili was grown on sucrose-casein medium amended with $1,4,16$, or $64 \mathrm{ppm}$ of these 13 fungicides, dimethyl sulphoxide (1\% vol/vol), and $1,000 \mathrm{ppm}$ each of streptomycin sulfate and penicillin-G. The range of fungicide rates allowed for identification of both slightly and highly active compounds. Fungicides and antibiotics were added immediately before pouring the medium into 100 - by $15-\mathrm{mm}$ Petri plates. Poured plates were allowed to stand for at least 3 days to allow for detection of bacterial contamination prior to use.

Inoculum for all experiments was prepared from a single-conidiospore isolate of E. mespili (EM93-5-1) originally isolated from infected saskatoon fruit collected near Barrhead, Alberta. Stock inoculum cultures for linear growth experiments were prepared by lightly grinding whole 13-day-old colonies of EM93-5-1 in approximately 5 $\mathrm{ml}$ sterile distilled water (SDW). The resulting suspension was spread evenly over unamended sucrose-casein medium. Stock cultures were incubated in darkness for 1 week at ambient temperature (approximately $22^{\circ} \mathrm{C}$ ), followed by 6 days in ambient fluorescent light at $25^{\circ} \mathrm{C}$. Plugs (4 $\mathrm{mm}$ diameter) of $E$. mespili taken from the stock culture were placed in the center of amended and unamended (control) sucrose-casein medium plates. Inoculated plates were incubated at ambient temperature in darkness for 28 days. Linear growth of each colony was determined by averaging two radii measured from the edge of the agar plug to the outer colony edge. Measurements were made on six replicate colonies for each fungicide $\times$ concentration combination. The experiment was repeated once.

The number of CFUs obtained from conidiospore suspensions was used to estimate the effect of the fungicides on spore germination. Suspensions were prepared by incubating EM93-5-1 under conditions described by van der Zwet and Stroo (19); 
sporulating colonies were flooded with a few $\mathrm{ml}$ of SDW and scraped with a glass rod. Resulting suspensions were adjusted to $6.25 \times 10^{5}$ conidia/ml with the aid of a hemacytometer. Petri plates filled with fungicide-amended and unamended sucrose-casein medium were inoculated with $200 \mu \mathrm{l}$ of the E. mespili conidiospore suspension spread evenly with a sterile glass rod. Inoculated plates were incubated in darkness at ambient temperature. The average number of $E$. mespili colonies in 10 microscopic fields was recorded for each plate 48 and $96 \mathrm{~h}$ after inoculation. There were three replicate plates for each fungicide $\times$ concentration treatment and the experiment was repeated once.

Data were analyzed as a completely randomized design using SAS statistical software (SAS Institute, Cary, NC). Analysis

Table 1. Effect of 12 fungicides on in vitro growth of Entomosporium mespili on amended sucrosecasein agar medium

\begin{tabular}{|c|c|c|c|c|}
\hline \multirow[b]{2}{*}{ Treatment } & \multicolumn{4}{|c|}{ Linear growth $(\mathbf{m m})^{w}$} \\
\hline & 1 ppm & 4 ppm & 16 ppm & $64 \mathrm{ppm}$ \\
\hline Control & $10.8 \pm 3.8$ & $9.6 \pm 4.5$ & $13.3 \pm 0.5$ & $12.1 \pm 3.1$ \\
\hline \multicolumn{5}{|l|}{ Contact fungicides } \\
\hline Chlorothalonil & $4.5 \pm 1.5$ & $4.4 \pm 0.6$ & $3.8 \pm 0.5$ & $3.9 \pm 0.8$ \\
\hline Mancozeb & $9.9 \pm 3.4$ & $8.3 \pm 0.6$ & $2.8 \pm 1.5$ & $0.3 \pm 0.7$ \\
\hline Anilazine & $\ldots^{\mathrm{x}}$ & $\ldots$ & $5.7 \pm 1.2$ & $4.1 \pm 0.7$ \\
\hline Iprodione & $5.1 \pm 1.3$ & $2.8 \pm 0.6$ & $3.5 \pm 0.8$ & $3.0 \pm 0.2$ \\
\hline \multicolumn{5}{|l|}{ Systemic EBI fungicides $y$} \\
\hline Triforine & $5.6 \pm 1.0$ & $5.2 \pm 0.8$ & $3.4 \pm 1.6$ & $0.0 \pm 0.0$ \\
\hline Imazalil & $0.0 \pm 0.0$ & $0.0 \pm 0.0$ & $0.0 \pm 0.0$ & $0.0 \pm 0.0$ \\
\hline Myclobutanil & $0.0 \pm 0.0$ & $0.0 \pm 0.0$ & $0.0 \pm 0.0$ & $0.0 \pm 0.0$ \\
\hline Propiconazole & $0.0 \pm 0.0$ & $0.0 \pm 0.0$ & $0.0 \pm 0.0$ & $0.0 \pm 0.0$ \\
\hline Triadimefon & $2.5 \pm 2.7$ & $0.1 \pm 0.2$ & $0.0 \pm 0.0$ & $0.0 \pm 0.0$ \\
\hline \multicolumn{5}{|l|}{ Systemic non-EBI fungicides } \\
\hline Thiophanate-methyl & $0.0 \pm 0.0$ & $0.0 \pm 0.0$ & $0.0 \pm 0.0$ & $0.0 \pm 0.0$ \\
\hline Benomyl & $0.0 \pm 0.0$ & $0.0 \pm 0.0$ & $0.0 \pm 0.0$ & $0.0 \pm 0.0$ \\
\hline Metalaxyl & $4.6 \pm 0.8$ & $4.7 \pm 0.4$ & $4.9 \pm 1.0$ & $4.6 \pm 0.6$ \\
\hline \multicolumn{5}{|l|}{ Contrasts $(\text { probability }>F)^{\mathrm{z}}$} \\
\hline Control vs. rest & 0.0001 & 0.0001 & 0.0001 & 0.0001 \\
\hline Contact vs. systemic & 0.0001 & 0.0001 & 0.0001 & 0.0001 \\
\hline EBI vs. non-EBI systemic & 0.6335 & 0.1400 & 0.0001 & 0.0001 \\
\hline
\end{tabular}

${ }^{\mathrm{w}}$ Mean colony diameter \pm standard deviation of six replicate plates taken 28 days after inoculation.

${ }^{x}$ No data.

${ }^{\mathrm{y}}$ Ergosterol-biosynthesis inhibitor.

${ }^{\mathrm{z}}$ Single degree-of-freedom group comparisons of in vitro fungicide treatment effects on E. mespili linear growth.

Table 2. Effect of 13 fungicides on colony formation of Entomosporium mespili on amended sucrose-casein agar medium

\begin{tabular}{lrrrr}
\hline & \multicolumn{3}{c}{ CFUs $^{\mathbf{w}}$} \\
\cline { 2 - 5 } Treatment & \multicolumn{1}{c}{$\mathbf{1} \mathbf{~ p p m}$} & \multicolumn{1}{c}{$\mathbf{4} \mathbf{~ p p m}$} & $\mathbf{1 6} \mathbf{~ p p m}$ & $\mathbf{6 4} \mathbf{~ p p m}$ \\
\hline Control & $29.1 \pm 6.9$ & $29.1 \pm 6.9$ & $30.4 \pm 6.5$ & $30.4 \pm 7.2$ \\
Contact fungicides & & & & \\
$\quad$ Chlorothalonil & $0.0 \pm 0.0$ & $0.0 \pm 0.0$ & $0.0 \pm 0.0$ & $0.0 \pm 0.0$ \\
$\quad$ Mancozeb & $50.0 \pm 32.0$ & $0.0 \pm 0.0$ & $0.0 \pm 0.0$ & $0.0 \pm 0.0$ \\
Anilazine & $12.2 \pm 7.1$ & $1.5 \pm 2.9$ & $0.0 \pm 0.0$ & $0.0 \pm 0.0$ \\
$\quad$ Iprodione & $21.1 \pm 9.7$ & $19.9 \pm 8.1$ & $0.0 \pm 0.0$ & $0.0 \pm 0.0$ \\
Systemic EBI fungicides ${ }^{\mathrm{x}}$ & & & & \\
$\quad$ Triforine & $0.0 \pm 0.0$ & $1.2 \pm 1.8$ & $0.0 \pm 0.0$ & $0.0 \pm 0.0$ \\
Imazalil & $10.2 \pm 6.2$ & $0.0 \pm 0.0$ & $0.0 \pm 0.0$ & $0.0 \pm 0.0$ \\
Myclobutanil & $0.0 \pm 0.0$ & $0.0 \pm 0.0$ & $0.0 \pm 0.0$ & $0.0 \pm 0.0$ \\
$\quad$ Propiconazole & $18.0 \pm 8.6$ & $3.5 \pm 5.7$ & $0.0 \pm 0.0$ & $0.0 \pm 0.0$ \\
$\quad$ Triadimefon & $0.1 \pm 0.3$ & $0.0 \pm 0.0$ & $0.0 \pm 0.0$ & $0.0 \pm 0.0$ \\
$\quad$ Tebuconazole & & & & \\
Systemic non-EBI fungicides & $0.0 \pm 0.2$ & $0.0 \pm 0.0$ & $0.0 \pm 0.0$ & $0.0 \pm 0.0$ \\
$\quad$ Thiophanate-methyl & $8.2 \pm 11.8$ & $0.0 \pm 0.0$ & $0.0 \pm 0.0$ & $0.3 \pm 1.0$ \\
Benomyl & $31.9 \pm 11.2$ & $23.5 \pm 11.3$ & $13.8 \pm 11.4$ & $0.0 \pm 0.0$ \\
$\quad$ Metalaxyl & & & & \\
Contrasts (probability $>F)^{\mathrm{z}}$ & 0.0001 & 0.0001 & 0.0001 & 0.0001 \\
$\quad$ Control vs. rest & 0.0001 & 0.0001 & 0.0001 & 0.8839 \\
Contact vs. systemic & 0.0001 & 0.0001 & 0.0001 & 0.8839 \\
EBI vs. non-EBI systemic &
\end{tabular}

${ }^{\text {w }}$ Mean number of colonies counted \pm standard deviation in each of 10 microscopic fields on each of three replicate plates.

${ }^{\mathrm{x}}$ Ergosterol-biosynthesis inhibitor.

y No data.

${ }^{\mathrm{z}}$ Single degree-of-freedom group comparisons of in vitro fungicide treatment effects on E. mespili colony formation.

of variance showed that all treatment effects were significant at all fungicide concentrations $(P<0.01)$. The efficacy of fungicides with different modes of action was examined using single degree-of-freedom (df) comparisons.

Field testing of fungicides. Trials were conducted at three commercial saskatoon orchards in 1995 and 1996. In 1995, treatments were applied to three trees (cv. Smoky) in each of four replicates in a randomized complete block design in orchards near Bowden, Seba Beach, and Spruce Grove, Alberta. Adjoining plots within replicates were separated by an unsprayed tree. One row of untreated trees divided the experimental plot area from the production area of each orchard. Average plant heights at Bowden, Seba Beach, and Spruce Grove were 2.9, 1.5, and $2.3 \mathrm{~m}$, respectively. Plants at Bowden, Seba, Beach and Spruce Grove were 16 to 17,5 , and 9 years old, respectively. Treatments were applied with a hand-held, $\mathrm{CO}_{2}$-propelled sprayer equipped with a hollow-cone nozzle at a pressure of $275 \mathrm{kPa}$. All treatments were applied to run-off. Water served as the control.

Fungicides were applied at growth stages selected in consultation with the fungicide suppliers. Benomyl, chlorothalonil, myclobutanil, and sulfur were applied at white-tip, petal-drop, green-fruit, and pre-harvest stages. Final pre-harvest sprays were applied 14 days before harvest for chlorothalonil and myclobutanil and seven days for benomyl and sulfur. Propiconazole was applied at white-tip, at petal-drop, and finally at the green-fruit stage; the last application was made 24 to 30 days before harvest. Triforine was applied at white-tip and petal-drop stages at Seba Beach and Spruce Grove with a pre-harvest interval of 30 days. Triforine was inadvertently sprayed a third time at Bowden at the green fruit stage, reducing the pre-harvest interval at this site to 24 days. Chlorothalonil was not applied at Spruce Grove due to space limitations.

Disease severity (DS) and disease incidence (DI) were evaluated at harvest, which occurred on 29 July 1995 at Spruce Grove and Seba Beach and on 4 August 1995 at Bowden. DS on fruit was determined by evaluating 30 racemes (10 per tree) from each plot using the 1 ( $0 \%$ of surface affected) to $12(100 \%$ of surface affected) Horsfall-Barratt disease severity index (10). DS on leaves was determined by examining five leaves on each of 10 fruit spurs or terminals per plant. Postharvest DS on leaves was evaluated at Spruce Grove, Seba Beach and Bowden on 14, 24, and 25 August 1995, respectively. DS values were back-transformed to percentages using the midpoint rule (3). DI was calculated as the percentage of fruit or leaves assigned a severity class rating of 2 or greater. DI data were arcsin-transformed prior to analysis (18). Data were analyzed 
using the General Linear Models procedure of SAS. $F$ values for treatment effects were significant $(P<0.01)$ for all sites.

Additional trials were conducted in 1996 at commercial saskatoon orchards near Calmar, Seba Beach, and Spruce Grove, Alberta on 7-, 5-, and 9-year-old A. alnifolia cv. Smoky plants, respectively. The two fungicides included in the 1996 trial were chlorothalonil (applied at 970 and $1,535 \mathrm{~g}$ a.i. $\mathrm{ha}^{-1}$ ) and propiconazole (applied at 125 and $190 \mathrm{~g}$ a.i. $\mathrm{ha}^{-1}$ ). Chlorothalonil was applied at bud-break, white-tip, petal-drop, and green fruit stages, whereas propiconazole was applied at white-tip, petal-drop, and green-fruit stages. Fruit was harvested 38 days after the last fungicide application. Fungicide application methods and plot layouts were otherwise the same as those used in 1995. DI and DS were evaluated four times at 9- to 15-day intervals. The first evaluations took place on 18 June at Seba Beach and Spruce Grove and on 25 June at Calmar. The last evaluation took place at harvest. DI and DS data were analyzed using procedures used in 1995.

Plants were monitored throughout the 1995 and 1996 seasons for phytotoxicity, and leaves and fruit from each plant were carefully examined for the presence of discoloration or deformation approximately 1 week after the last application of fungicide.

\section{RESULTS}

In vitro screening of fungicides against $\boldsymbol{E}$. mespili. Of the fungicides tested, benomyl, imazalil, myclobutanil, propiconazole, and thiophanate-methyl completely restricted growth of the pathogen at 1 ppm a.i. (Table 1). Conversely, anilazine, chlorothalonil, iprodione, mancozeb, and metalaxyl failed to completely inhibit growth even at 64 ppm a.i., the highest rate tested. Microscopic examination indicated that germinated and ungerminated E. mespili conidiospores could not easily be distinguished after $48 \mathrm{~h}$ of incubation on unamended sucrose-casein medium due to the presence of setae on the conidiospores. This precluded the use of direct observation of conidiospores for evaluation of fungicide effects on $E$. mespili spore germination. After $96 \mathrm{~h}$ of incubation, however, conidiospores had germinated and formed discrete minute colonies; therefore, the number of CFUs was used to observe the effect of fungicides on spore germination.

Colony formation by E. mespili was completely inhibited by chlorothalonil, imazalil, propiconazole, and thiophanatemethyl at $1 \mathrm{ppm}$ a.i. (Table 2). All fungicides, except anilazine, iprodione, metalaxyl, triadimefon, and triforine, prevented conidiospore germination at $4 \mathrm{ppm}$ a.i. Imazalil, propiconazole, and thiophanatemethyl prevented both colony growth and conidiospore germination at all concentrations tested. Chlorothalonil prevented conidiospore germination at $1 \mathrm{ppm}$ a.i. (Table 2), but did not prevent mycelial growth at $64 \mathrm{ppm}$ a.i. (Table 1).

Single df group comparisons showed that systemic fungicides were significantly more effective in inhibiting colony growth and conidiospore germination than contact fungicides (Tables 1 and 2). Ergosterolbiosynthesis-inhibiting fungicides (EBIs) did not differ from systemic non-EBIs in their ability to inhibit colony growth at 1 ppm (Table 1), but were significantly more effective in inhibiting spore germination (Table 2). This may be due to the slightly inhibitory effect of metalaxyl on colony growth and the failure of benomyl to completely inhibit colony formation at $1 \mathrm{ppm}$ a.i. Similar results were obtained when in vitro experiments were repeated (data not shown).

Field testing of fungicides. Chlorothalonil substantially reduced DS on fruit in 1995 (Table 3). Benomyl reduced DS over controls and triforine, the standard fungicide in this test, at Seba Beach and Spruce Grove, but not at Bowden, the most severely affected site. Propiconazole application significantly reduced DS over controls or triforine at Bowden and Seba Beach, but not at Spruce Grove. Sulfur reduced DS at Spruce Grove to a level equivalent to that attained with benomyl, but was not effective at the other two sites. With the exception of triforine, all fungicides significantly reduced DS at Seba Beach and Spruce Grove in the post-harvest period (Table 4). Similar trends were observed at Bowden, except that myclobutanil did not reduce DS. Benomyl significantly reduced DI on fruit at Spruce Grove and Seba Beach relative to the control (Table 3) and post-harvest DI at Spruce Grove (Table 4). Chlorothalonil reduced DI on fruit and post-harvest DI at Seba Beach. Propiconazole reduced post-harvest DI at Seba Beach. No phytotoxic effects were observed on leaves or fruit in 1995 or 1996.

High ELBS incidence and severity levels in control treatments at all three sites indicated that disease pressure was very high in 1996. Figure 1 shows results from the Calmar site. Chlorothalonil and propiconazole effectively reduced DS at Calmar and Seba Beach. Both application rates of chlorothalonil and propiconazole significantly $(P<0.05)$ reduced DS over control treatments on leaves and fruit at harvest at these sites, according to a Tukey's mean separation test. The fungicides were also

Table 3. Effect of fungicide application on Entomosporium leaf and berry spot severity and incidence on fruit at harvest at three commercial saskatoon orchards in Alberta in 1995 ${ }^{\mathrm{w}}$

\begin{tabular}{|c|c|c|c|c|c|c|}
\hline \multirow[b]{2}{*}{ Treatment $^{\mathrm{x}}$} & \multicolumn{2}{|c|}{ Bowden } & \multicolumn{2}{|c|}{ Seba Beach } & \multicolumn{2}{|c|}{ Spruce Grove } \\
\hline & DS $^{\mathbf{y}}$ & $\mathbf{D I}^{\mathbf{z}}$ & DS & DI & DS & DI \\
\hline Chlorothalonil $(1,500)$ & $8.6 \mathrm{a}$ & $82.8 \mathrm{a}$ & $1.0 \mathrm{a}$ & $33.5 \mathrm{ab}$ & & \\
\hline Benomyl (550) & $35.6 \mathrm{abc}$ & $92.5 \mathrm{a}$ & $0.9 \mathrm{a}$ & $29.5 \mathrm{a}$ & $1.5 \mathrm{a}$ & $34.4 \mathrm{a}$ \\
\hline Propiconazole (190) & $15.5 \mathrm{ab}$ & $84.9 \mathrm{a}$ & $1.4 \mathrm{ab}$ & $44.6 \mathrm{abc}$ & $3.5 \mathrm{ab}$ & $54.4 \mathrm{ab}$ \\
\hline Sulfur (600) & $21.2 \mathrm{abc}$ & $84.7 \mathrm{a}$ & $3.9 \mathrm{abc}$ & $64.9 \mathrm{c}$ & $2.4 \mathrm{a}$ & $37.6 \mathrm{ab}$ \\
\hline Myclobutanil (136) & $38.7 \mathrm{abc}$ & $96.0 \mathrm{a}$ & $4.6 \mathrm{c}$ & $64.0 \mathrm{bc}$ & $4.6 \mathrm{ab}$ & $58.7 \mathrm{ab}$ \\
\hline Triforine (570) & $52.7 \mathrm{c}$ & $96.9 \mathrm{a}$ & $4.7 \mathrm{c}$ & $67.6 \mathrm{c}$ & $7.1 \mathrm{~b}$ & $71.8 \mathrm{~b}$ \\
\hline Control & $45.9 \mathrm{c}$ & $98.2 \mathrm{a}$ & $4.5 \mathrm{bc}$ & $72.2 \mathrm{c}$ & $5.7 \mathrm{bc}$ & $65.1 \mathrm{ab}$ \\
\hline
\end{tabular}

${ }^{\mathrm{w}}$ Mean of four replications. Numbers in a column followed by the same letter are not significantly different according to a Tukey's studentized range test $(P<0.05) ; \ldots=$ no data.

$x$ Treatment and rate $\left(\mathrm{g}\right.$ a.i. $\left.\mathrm{ha}^{-1}\right)$.

${ }^{\text {y }}$ DS = disease severity. Horsfall-Barratt disease severity index back-transformed to percent area affected.

${ }^{\mathrm{z}} \mathrm{DI}=$ disease incidence. Arcsin-transformed percentage of fruit in Horsfall-Barratt severity classes 2 to 12 . Back-transformed values are presented here.

Table 4. Effect of fungicide application on post-harvest disease severity and incidence of Entomosporium leaf and berry spot severity and incidence on leaves at three commercial saskatoon orchards in Alberta in $1995^{\mathrm{w}}$

\begin{tabular}{|c|c|c|c|c|c|c|}
\hline \multirow[b]{2}{*}{ Treatment $^{\mathrm{x}}$} & \multicolumn{2}{|c|}{ Bowden } & \multicolumn{2}{|c|}{ Seba Beach } & \multicolumn{2}{|c|}{ Spruce Grove } \\
\hline & DS $^{\mathbf{y}}$ & DI $^{\mathbf{z}}$ & DS & DI & DS & DI \\
\hline Chlorothalonil $(1,500)$ & $16.5 \mathrm{a}$ & $100.0 \mathrm{a}$ & $10.9 \mathrm{a}$ & 89.9 a & & \\
\hline Benomyl (550) & $64.3 \mathrm{~cd}$ & $100.0 \mathrm{a}$ & $9.6 \mathrm{a}$ & $90.0 \mathrm{a}$ & $5.1 \mathrm{a}$ & $90.8 \mathrm{a}$ \\
\hline Propiconazole (190) & $30.0 \mathrm{~b}$ & $100.0 \mathrm{a}$ & $31.5 \mathrm{~b}$ & $98.3 \mathrm{~b}$ & $29.3 \mathrm{~b}$ & $98.3 \mathrm{~b}$ \\
\hline Sulfur (600) & $55.0 \mathrm{c}$ & $100.0 \mathrm{a}$ & $38.7 \mathrm{bc}$ & $99.2 \mathrm{~b}$ & $23.5 \mathrm{~b}$ & $100.0 \mathrm{~b}$ \\
\hline Myclobutanil (136) & $67.6 \mathrm{de}$ & $100.0 \mathrm{a}$ & $50.0 \mathrm{c}$ & $99.2 \mathrm{~b}$ & $29.5 \mathrm{~b}$ & $99.2 \mathrm{~b}$ \\
\hline Triforine $(570)$ & $77.4 \mathrm{e}$ & $100.0 \mathrm{a}$ & $66.5 \mathrm{~d}$ & $100.0 \mathrm{~b}$ & $47.5 \mathrm{c}$ & $100.0 \mathrm{~b}$ \\
\hline Control & $75.8 \mathrm{e}$ & $100.0 \mathrm{a}$ & $65.7 \mathrm{~d}$ & $100.0 \mathrm{~b}$ & $51.1 \mathrm{c}$ & $100.0 \mathrm{~b}$ \\
\hline
\end{tabular}

${ }^{\mathrm{w}}$ Mean of four replications. Numbers in a column followed by the same letter are not significantly different according to a Tukey's studentized range test $(P<0.05) ; \ldots=$ no data.

x Treatment and rate $\left(\mathrm{g}\right.$ a.i. $\left.\mathrm{ha}^{-1}\right)$.

${ }^{y}$ DS -= disease severity. Horsfall-Barratt disease severity index back-transformed to percent area affected.

${ }^{\mathrm{z}} \mathrm{DI}=$ disease incidence. Arcsin-transformed percentage of fruit in Horsfall-Barratt severity classes 2 to 12 . Back-transformed values are presented here. 
effective in reducing DS on leaves at harvest at Spruce Grove; however, a similar effect on fruit was not observed at this site. Spruce Grove was the most severely affected site in 1996. The effect of fungicide application on DI in 1996 varied greatly among test sites. Propiconazole (190 $\mathrm{g} \mathrm{ha}^{-1}$ ) reduced ELBS incidence on fruit at harvest at Seba Beach; incidence on fruit at harvest was not affected by fungicide treatment at the remaining two sites.

\section{DISCUSSION}

ELBS first became prominent in Alberta in 1990, when it caused severe fruit damage in several commercial saskatoon orchards. A high proportion of the bushes examined in an ELBS survey carried out at that time was severely affected (16). Results of surveys conducted throughout Alberta in 1993 and 1994 again showed that the disease was widespread and serious (11-14).

In vitro testing of fungicides on $E$. mespili identified a number of compounds that suppressed mycelial growth or conidiospore germination. Of the effective fungicides, five were EBIs (imazalil, myclobutanil, propiconazole, tebuconazole, and triforine), three were systemic benzimidazoles (benomyl, thiabendazole, and thiophanate-methyl) and one was a nonsystemic phthalamide (chlorothalonil). Walker (20) also reported that a large number of fungicides were effective against E. mespili isolates from photinia, some of which were inhibitory at concentrations of less than $1 \mathrm{ppm}$. It is therefore possible that several fungicides from different chemical families and with different modes of action are available for use against ELBS. The use of such fungicide combinations forestall development of fungicide-resistant $E$. mespili, which has been observed on photinia (8).

Application of sulfur to orchard-grown saskatoon plants was reported to significantly reduce levels of ELBS, rust (Gymnosporangium spp.), and brown rot (Monilinia amelanchieris), but also caused phytotoxicity (17). Our data showed significant disease control in 1995 at one-half the rate used by St. Pierre and Kaminski (17) with no apparent phytotoxicity.

Previous reports have indicated that multiple fungicide applications are required to achieve acceptable levels of control of entomosporium diseases. Bowen et al. (2) observed significant reductions in disease levels as applications of chlorothalonil, myclobutanil, and tebuconazole increased and Hagan et al. (9) reported that myclobutanil applied to

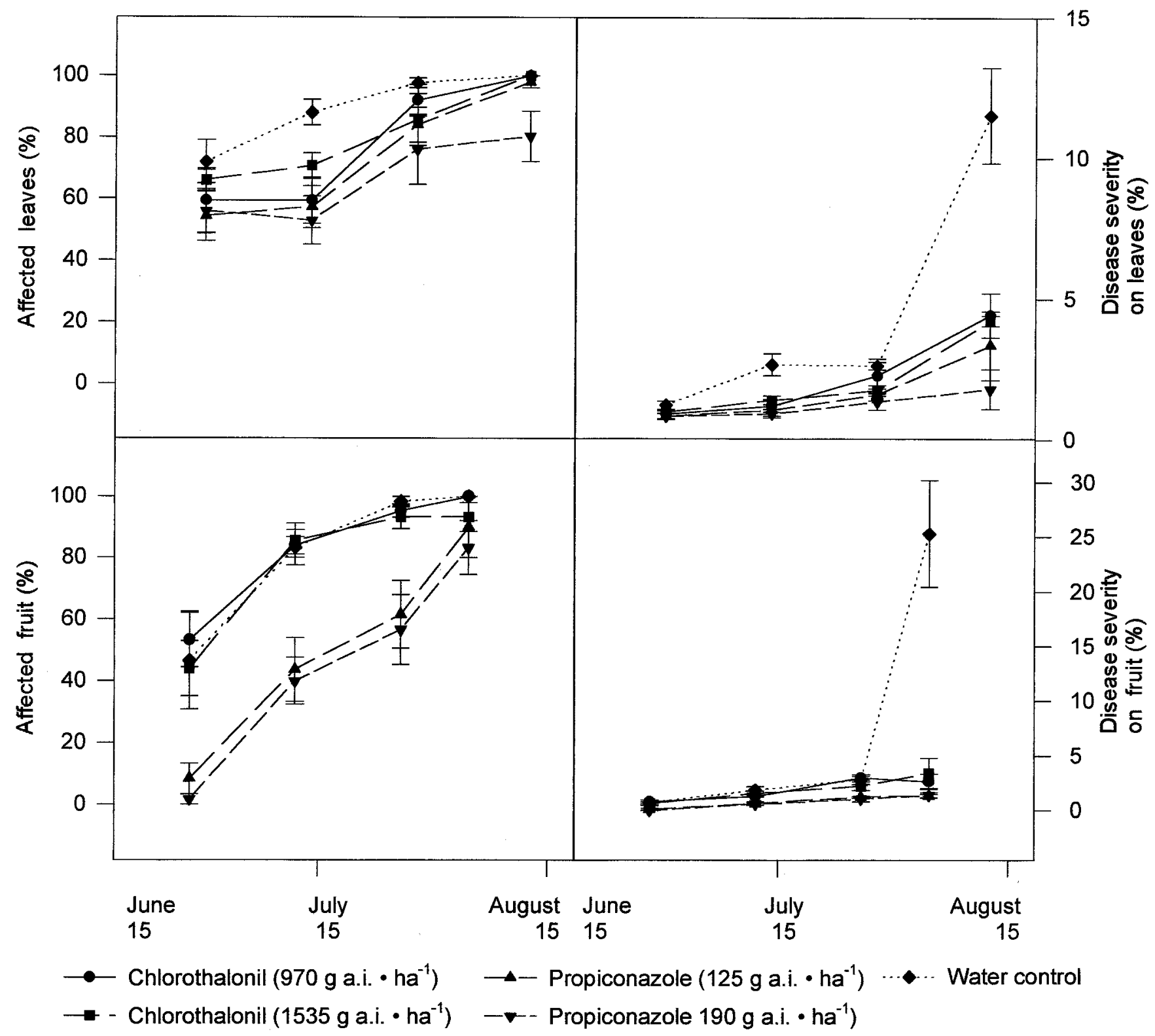

Fig. 1. Effect of fungicide application on Entomosporium leaf and berry spot incidence and severity in a commercial saskatoon orchard near Calmar, Alberta in 1996. Each point is the mean of four replications. Vertical lines indicate standard error of the mean. 
photinia at 1- or 2-week intervals provided good control of Entomosporium leaf spot of photinia, but did not reduce DI when applied at 4-week intervals. A minimum of four fungicide applications was required to protect pear fruit and foliage from $E$. mespili (4). The ineffectiveness of single fungicide applications against ELBS in a preliminary saskatoon orchard trial strongly suggests that multiple, and perhaps frequent, fungicide sprays are required for effective control of the disease on saskatoon (1).

A broad range of fungicides has been found to be effective against E. mespili. Several studies list chlorothalonil as an effective fungicide for control of Entomosporium leaf spot of photinia (Photinia serrulata and Photinia $\times$ fraseri; $2,8,9,20)$. Chlorothalonil has long been known to be effective in controlling Entomosporium leaf spot of pear (4). Benzimidazoles $(15,20)$ and EBIs are also effective against E. mespili (2). One EBI fungicide, triforine, has proven effective and is registered for use on saskatoons in Canada (17). However, this product did not control ELBS when applied in commercial saskatoon orchards in Alberta in 1994. Published reports concerning the performance of triforine are contradictory. Cobb et al. (5) reported that triforine gave a level of control equal to or greater than that of chlorothalonil or propiconazole, while other reports suggest that benomyl, chlorothalonil, and myclobutanil give more complete control of Entomosporium leaf spot of photinia $(2,7,9,20)$. The reported efficacy of benzimidazole fungicides also varies. Walker (20) found that benomyl gave effective control of Entomosporium leaf spot of photinia at recommended rates, while growers found that benomyl was ineffective in controlling the disease (8). Furthermore, benomyl and thiophanatemethyl, unlike chlorothalonil, did not control the disease when tested (8). These reports suggest that E. mespili may be capable of developing resistance to benzimidazole fungicides.

Chlorothalonil and propiconazole were chosen for further orchard testing because of their efficacy in the in vitro tests and the 1995 orchard trial. Moreover, these compounds are from different chemical families and differ in their modes of action, which should facilitate resistance man- agement of E. mespili. Chlorothalonil and propiconazole both substantially reduced DS on leaves and fruit at two saskatoon orchard test sites in 1996, but did not control ELBS on fruit at the third site (Spruce Grove). Disease control efficacy of either fungicide at the low application rate did not differ from that observed at the high rate. Unfortunately, fungicide application in general did not affect DI in this study. Producers may find it difficult to produce a high proportion of unblemished fruit in the face of severe disease pressure. Neither fungicide was effective at Spruce Grove, where disease pressure was high, even at the high rate. This suggests that application rate is not the most important determinant of the control level ultimately achieved.

The timing and frequency of sprays may be more important than application rate in ELBS control. ELBS disease progress curves were characterized by substantial increases in DI and DS in the 30 days preceding harvest. Disease development may be favored by increased relative humidity caused by the closing crop canopy and by profuse sporulation on ripening fruit. It may therefore be prudent to apply fungicides at shorter intervals than 14 days in the 30-day preharvest period. A fungicide application between 15 July and harvest (29 July) may have substantially reduced DS at Spruce Grove in 1996.

The results of this work indicate that chlorothalonil and propiconazole can effectively control ELBS. However, further studies are required to optimize the timing and frequency of fungicide application.

\section{ACKNOWLEDGMENTS}

We thank grower cooperators N. Bamber, L. Pearson, M. Turta, and J. Uhryn; M. Briant, P. Taschuk, and M. Yu for technical assistance; and C. Thomson for reviewing the manuscript.

\section{LITERATURE CITED}

1. Bains, P. S., Lange, R. M., and Howard, R. J. 1996. Development of a fungicidal control program for Entomosporium leaf and berry spot of saskatoon. Alberta Agric. Res. Inst., Farming for the Future Res. Prog. Proj. No. 93-0290.

2. Bowen, K. L., Hagan, A. K., Olive, J., and Foster, W. 1994. Application rates and spray intervals of ergosterol-biosynthesis inhibitor fungicides for control of Entomosporium leaf spot of photinia. Plant Dis. 78:578-581.

3. Campbell, C. L., and Madden, L. V. 1990. Introduction to Plant Disease Epidemiology. Wiley-Interscience, New York.

4. Chandler, W. A. 1967. Fungicidal control of
Fabrea leafspot of pear. Plant Dis. 51:257-261.

5. Cobb, G. S., Hagan, A. K., Gilliam, C. H., and Mullen, J. M. 1985. Fungicidal control of Entomosporium leaf spot on Photinia. Plant Dis. 69:684-685.

6. Davidson, J. G. N., Bains, P. S., Pesic Van Esbroeck, Z., and Kaminski, D. A. 1991. Epidemic of Entomosporium berry and leaf spot of saskatoons throughout Alberta in 1990. Can. Plant Dis. Surv. 71:123-124.

7. Hagan, A., Foster, W. J., and Parrott, L. Jr. 1989. Efficacy of new fungicides for the control of Entomosporium leaf spot on Photinia. Res. Rep. Ser., Ala. Agric. Exp. Stn., Auburn Univ. 6:6-7.

8. Hagan, A. K., Gilliam, C. H., Mullen, J. M., Crockett, J. S., and Shumack, R. L. 1983 Fungicidal control of Entomosporium leaf spot on Photinia. J. Environ. Hortic. 1:31-33.

9. Hagan, A. K., Olive, J., and Foster, W. J. 1991. Effect of Nova fungicide on Entomosporium leaf spot on photinia. Res. Rep. Ser., Ala. Agric. Exp. Stn., Auburn Univ. $7: 35$.

10. Horsfall, J. G., and Barratt, R. W. 1945. An improved grading system for measuring plant diseases. (Abstr.) Phytopathology 35:655.

11. Howard, R. J., Briant, M. A., and Sims, S. M. 1994. Saskatoon leaf and berry spot in southcentral Alberta in 1993. Can. Plant Dis. Surv. 74:120-122.

12. Howard, R. J., Briant, M. A., and Sims, S. M. 1995. Saskatoon leaf and berry spot in southcentral Alberta in 1994. Can. Plant Dis. Surv. 75:182-184.

13. Lange, R. M., and Bains, P. S. 1994. Survey of Entomosporium leaf and berry spot of saskatoon in 1993. Can. Plant Dis. Surv. 74:12324.

14. Lange, R. M., and Bains, P. S. 1995. Survey of Entomosporium leaf and berry spot of saskatoon in 1994. Can. Plant Dis. Surv. 75:180181.

15. Nunes, J. M. S. 1986. Testing of fungicides to control Entomosporium disease of quince (Cydonia vulgaris). Fitopatol. Bras. 11:245248.

16. Pesic-van Esbroeck, Z., Bains, P. S., and Motta, J. A. 1991. Survey for common leaf spot, blight and berry spot of saskatoon in central Alberta. Can. Plant Dis. Surv. 71:125.

17. St. Pierre, R. G., and Kaminski, D. A. 1993 Triforine, metiram and sulfur for control of saskatoon-juniper rust, brown rot, and Entomosporium leaf and berry spot, 1992-1993. No. 105. Pest Manage. Res. Rep. 1993. Agric. Can. Res. Branch, Ottawa, ON.

18. Steel, R. G. D., and Torrie, J. H. 1980. Principles and Procedures of Statistics. 2nd ed. McGraw-Hill Book Co., New York.

19. van der Zwet, T., and Stroo, H. F. 1985. Effects of cultural conditions on sporulation, germination, and pathogenicity of Entomosporium maculatum. Phytopathology 75 : 94-97.

20. Walker, J. T. 1992. Factors affecting fungicidal control of Entomosporium leaf spot of photinia. J. Environ. Hortic. 10: 145-149. 